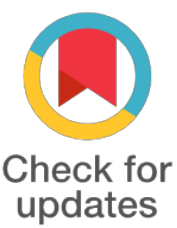

*For correspondence:

tungson94@gmail.com

Competing interests: The authors declare that no competing interests exist.

Received: 2017-07-13

Accepted: 2017-08-04

Published: 2017-09-05

Copyright The Author(s) 2017. This article is published with open access by BioMedPress (BMP).

This article is distributed under the terms of the Creative Commons Attribution License (CC-BY 4.0) which permits any use, distribution, and reproduction in any medium, provided the original author(s) and the source are credited.

POSTER

\section{Antifungal prophylaxis in hematopoietic stem cell transplantation recipients: drug use evaluation at Vietnam National Institute of Hemotology and Blood transfusion}

\author{
Son Nguyen T., Hoa M. Nguyen, Anh H. Nguyen, Tan D. Nguyen, Binh TT. \\ Vo
}

National DI \& ADR Center, Hanoi University of Pharmacy, Ha Noi, Vietnam

\begin{abstract}
Background: Hematopoietic stem cell transplantation (HSCT) recipients were known to be in high risk of fungal infection. However, not all HSCT patients need antifungal prophylaxis. The aim of this study was to describe the characteristics of the use of antifungal prophylaxis in hematopoietic stem cell transplantation recipients and to evaluate the appropriateness of use.
\end{abstract}

Methods: In this observational prospective study, adult hematopoietic stem cell transplantation recipients without using antifungal treatment were recruited from start of stem cell transfusion in Vietnam National Institute of Hematology and Blood Transfusion (from April to December 2016) to end of antifungal prophylaxis or start of antifungal treatment. Appropriateness was defined based on National Comprehensive Cancer Network (NCCN) guidelines. Clinically significant Drug-drug interactions related to antifungals were defined based on Hansten and Horn's Drug interaction and management 2013.

Results: 38 patients (mean age: $35.7 \pm 12.0 ; 57.9 \%$ male) were admitted, included 21 autologous and 17 allogeneic HSCT recipients. After HSCT, 3 deaths, 1 to ICU, $1 \mathrm{IFI}$. Azoles prophylaxis was given to $100 \%$ of patients with median 17.5 days $(13-47.5)$. Fluconazole was the most used antifungal agents, in $94.7 \%$ of patients and $74.5 \%$ of episodes. 10 patients had been changed antifungal agents. Indication was appropriate in $44.7 \%, 0 \%$ in autologous and $100 \%$ in allogeneic group. In patients with appropriate indication, choice of antifungal agents was $100 \%$ appropriate. $100 \%$ of patients used inappropriate dosage, mostly lower than recommeded dosage with azoles. $\mathbf{1 2 . 7} \%$ had appropriate prophylactic time. Potential drug-drug interactions were identified in $92.1 \%$ of patients. Most frequent interactions involved azoles-diazepam ( $80.4 \%$ of episodes) and azoles-immunosuppressive drugs ( $49 \%$ of episodes).

Conclusion: Our evaluation revealed a high proportion of inappropriate of antifungal prophylaxis. An antifungal stewardship programme is needed to strengthen rational use of antifungal in this specific circumstance. 


\section{Keywords}

Antifungal prophylaxis; Drug use evaluation; Hematopoietic stem cell transplantation

\section{Funding}

\section{References}

1. National Comprehensive Cancer Network (2015), "Prevention and Treatment of CancerRelated Infections (Version 2.2015)".

2. National Comprehensive Cancer Network (2016), "Prevention and Treatment of CancerRelated Infections (Version 2.2016)".

3. Hansten P.D., Horn J.R. (2013), Hansten and Horn's Drug Interactions Analysis and Management, Lippincott Williams \& Wilkins, St. Louis.

4. Vazin A., Davarpanah M. A., et al. (2015), "Antifungal agent utilization evaluation in hospitalized neutropenic cancer patients at a large teaching hospital", Drug Healthc Patient Saf, 7, pp. 97-102.

5. Nivoix Y., Launoy A., et al. (2012), "Adherence to recommendations for the use of antifungal agents in a tertiary care hospital", J Antimicrob Chemother, 67(10), pp. 2506-13. 